\title{
Influence of Inlet Drying Temperature on the Physical Attributes of Spray Dried Avocado (Persea americana Mill) Powder
}

\author{
V.S. Karthik Nayaka ${ }^{1}$, Shamina Azeez ${ }^{2}$, G. J. Suresha ${ }^{1}$, R. B. Tiwari ${ }^{2}$, \\ S. J. Prasanth ${ }^{3}$, G. Karunakaran ${ }^{4}$ and K. B. Suresha ${ }^{5}$ \\ ${ }^{1}$ Department of Post-harvest technology, UHS, Bagalkot, India \\ ${ }^{2}$ Division of Post-harvest technology \& Agricultural engineering, ICAR-IIHR, India \\ ${ }^{3}$ Department of Vegetable Science, UHS, Bagalkot, India \\ ${ }^{4}$ Division of Fruit Crops, ICAR-IIHR, Hessaraghatta, India \\ ${ }^{5}$ AICRP on Post Harvest technology, GKVK-UAS, Bengaluru, India \\ *Corresponding author
}

\section{A B S T R A C T}

\begin{tabular}{|l|}
\hline K e y w o r d s \\
Spray drying, \\
Micro- \\
Encapsulation, Inlet \\
temperature, \\
Physical attributes \\
\hline Article Info \\
\hline $\begin{array}{l}\text { Accepted: } \\
\text { 14 November } 2020 \\
\text { Available Online: } \\
\text { 10 December } 2020\end{array}$ \\
\hline
\end{tabular}

\section{Keywords}

Spray drying,

Encapsulation, Inlet temperature,

Physical attributes

Article Info

14 November 2020

10 December 2020

\begin{abstract}
Avocado has gained high importance for its healthy fatty acid and phytosterols profile which the human body demands. Parallel to it, the highly perishable nature of this tropical fruit crop will shorten its shelflife. Therefore, spray drying would be the alternative technology to obtain a nutritious and shelf-stable powder. The avocado juice was spray dried at different temperatures and was analysed for its physical properties. Results showed that higher drying temperature favoured in achieving residual moisture content, water activity, and bulk density. Whereas the colour of the powder was gradually lost at a higher temperature and better yield was obtained at an intermediate inlet drying temperature.
\end{abstract}

\section{Introduction}

Avocado, a subtropical fruit crop originated from central America, botanically fruit is a drupe with a smooth or coarse olive green, purple or black color skin. It's highly valued for its greenish-yellow pulp. This classical fruit is rich in many nutrients and phytochemicals (Comeford et al., 2016). The biochemical makeup of the fruit makes it so important as it is rich in healthy fat i.e., monounsaturated fatty acids with omega- 3 fatty acids which are capable of boosting cardiac and brain health (Minh et al., 2019). It is enriched with lipophilic phytochemicals such as sterols, alkaloids, and volatiles. They are also a rich source of various vitamins such as E, C, B6, Beta-Carotene (RodriguezSanchez et al., 2015). In addition, they are rich sources of dietary fiber and mineral 
compounds. In general, avocado consumers had a higher daily consumption of fruits and vegetables, essential foods included in a healthy diet for reduction or maintenance of the bodyweight (Sloth, 2009; Champagne, 2011). The physiologically avocado is a typically climacteric fruit, generating a high amount of $\mathrm{CO} 2$ and ethylene during the process of ripening and hence, it's highly perishable. However, a significant challenge is to maintain its high nutritional value in fresh or processed form. Auto-oxidation of lipid and high levels of enzyme activity such as Polyphenol oxidase and peroxidase causing browning are the limiting factors. In addition, contributions of enzymes such as lipoxygenase and lipase in altering the biochemical composition of pulp result in lessening the quality, taste, and storage life.

In food processing and preservation, drying plays a vital role from a way back to being more efficient and practically sensible. Though drying can increase the shelf life of the final product, several bioactive compounds such as vitamins, ascorbic acid, and other pigments are thermolabile and highly unstable (Rawson et al., 2011). Among the different drying methods, spray drying is a unique and well-established technique for transforming the liquid fruit juices into powder through the one-step process with or without using the coating material. Though different fruit juices have been dried using spray drying the avocado pulp is scarcely studied due to the high-fat content and severe extent of enzymatic browning caused by Polyphenols oxidase. Inlet temperature, type, and concentration carrier agent, and feed flow are the major operating variables affecting the quality of the spray-dried powder. With respect to the quality of the powder, physical attributes play a vital role. In this regard, efforts were made to understand the influence of different drying inlet temperatures on the physical attributes of the spray-dried avocado powder using an industrial-scale spray drier.

\section{Materials and Methods}

\section{Materials}

Fresh avocado fruits used in this experiment, was produced at the Central Horticultural Experimental Station (CHES), Chettalli, Karnataka. Fruits were hand-picked which were uniform in size, shape, and maturity, free from visible damages was selected and carefully placed in corrugated fiberboard boxes and brought to ICAR-IIHR, Bengaluru campus.

\section{Preparation of avocado juice}

Care was taken so that each fruit was washed using clean water, cut into halves, seed with coat were removed and the pulp was scooped out. The scooped pulp was directly taken into a homogenizer and was diluted in the ratio of 1:1.5 using portable RO water. Soon after the dilution, the juice was filtered using the muslin cloth to avoid blocking of the atomizer of the spray dryer. Finally, the required quantity of citric acid, maltodextrin was added and blended uniformly using the homogenizer.

\section{Food additives}

The citric acid, soya lecithin, and Maltodextrin used in the experiment were all of the food-grade material. In this study we choose maltodextrin having $\mathrm{DE}=10$.

\section{Spray drying}

The spray drying operation was carried out at AICRP on Postharvest Technology, GKVK, UAS, Bengaluru. The pilot-scale spray dryer (R\&D, Milk Tech. Engineers, Manufacturer \& Supplier Pvt. Ltd, India)equipped with a nozzle size of $1 \mathrm{~mm}$ and air pressure of $4 \mathrm{~kg}$ / $\mathrm{cm}^{2}$ was used in this experiment. 


\section{Experimental details}

The experiment was setup at Division of PostHarvest Technology \& Agricultural Engineering, ICAR-Indian Institute of Horticultural Research (IIHR), Hessaraghatta, Bengaluru, and College of Horticulture, Bengaluru, (University of Horticultural Sciences, Bagalkot), Karnataka, during 2016 - 2017. In the spray drying process feed flow of $10 \mathrm{ml} / \mathrm{min}$ and $10 \%$ maltodextrin was maintained constant throughout the experiment. Drying inlet temperature was varied from $150{ }^{\circ} \mathrm{C}, 160{ }^{\circ} \mathrm{C}, 170{ }^{\circ} \mathrm{C}$, and 180 ${ }^{\circ} \mathrm{C}$. After completion of the spray drying the samples were collected from the product collection vessel and packed in aluminum laminated pouches until further analysis.

\section{Analysis of the spray-dried powder}

The spray-dried powders were analyzed in 5 replicates for the moisture content, water activity, color ( $\mathrm{L}$ a b C H), wettability, bulk density, tap density, Hausner ratio, Carr's index, and powder yield.

\section{Physical properties}

\section{Moisture (\%)}

The moisture content of the powder was determined by drying the powder at $130{ }^{\circ} \mathrm{C}$ using an electronic moisture analyzer, Sartorius MA 35, and the moisture content was expressed in terms of percent.

\section{Water activity}

Water activity is the ratio of the partial vapor pressure of water in a product to the partial vapor pressure of pure water at the same temperature. The water activity of the encapsulated avocado powder was measured using an electric water activity meter, Rotronic Hydrolab, UK, at $25^{\circ} \mathrm{C}$.

\section{Colour ( $L a b C \mathrm{C}$ values)}

For estimation of color, Lovibond color meter (Lovibond RT300, Portable spectrophotometer, Tintometer Limited, Salisbury, UK) fitted with $8 \mathrm{~mm}$ aperture and the instrument was adjusted at $10^{\circ}$ observers and D65 primary illuminant was used. The instrument was calibrated using the black and white tiles provided. The color of the spraydried avocado powder was measured using a Color was expressed in Lovibond units $\mathrm{L}^{*}$ which refer to the lightness of product which will range from darkness-lightness (0-100), a* refer to greenness - redness (-120 to 120) where negative values indicate greenness and positive indicate redness.

Similarly, $b^{*}$ values refer to blueness yellowness (-120 to 120) where negative values indicate blueness and positive values indicate yellowness. Chroma $\left(\mathrm{C}^{*}\right)$ and hue angle $\left(\mathrm{h}^{\circ}\right)$ were calculated by $\left[\left(\mathrm{a}^{*}\right)^{2}+\left(\mathrm{b}^{*}\right)^{2}\right]^{1 / 2}$ and $\tan ^{-1}\left(\mathrm{~b}^{*} / \mathrm{a}^{*}\right)$ respectively. To obtain these values, the lens of the color reader was placed over the powder in special cuvettes.

\section{Wettability}

The wettability was evaluated as per the method described by Vissotto et al., (2010) and expressed in terms of the time required for one gram of powder deposited on the liquid surface to become completely submerged in $400 \mathrm{ml}$ of distilled water at $25^{\circ} \mathrm{C}$.

\section{Bulk density (g/ml)}

Bulk density (g/ml) was determined by pouring $20 \mathrm{~g}$ of powder gently into an empty $100 \mathrm{ml}$ graduated cylinder. The volume was registered, and the ratio of powder mass and the volume occupied in the cylinder was used to determine the bulk density. 


\section{Tap density}

Tap density $(\mathrm{g} / \mathrm{ml})$ was determined by pouring $20 \mathrm{~g}$ of powder into a $100 \mathrm{ml}$ graduated cylinder followed by tapping 100 times. The volume was registered, and the ratio of powder mass and the volume occupied in the cylinder was used to determine the tap density.

\section{Hausner ratio (Hausner, 1967)}

Hausner ratio is a measure of cohesiveness and it's determined by the ratio of tap density and bulk density.

\section{Tap Density \\ Hausner ratio: Bulk Density \\ Carr's index (Carr's 1965)}

Carr's index is a flow-ability test that indicates the compressibility of powder which is obtained using the formula below.

Carr's index:

$100 * \frac{\text { (Tapped Density-Bulk Density) }}{\text { (Tapped Density) }}$

\section{Powder yield (\%)}

The percent yield of spray-dried was expressed as the ratio of powder collected in the cyclone and deposited on drier walls to the weight of feed mixture consumed on a fresh weight basis. The following equation was used for calculating the yield:

Powder Yield $(\%)=$

Weight of spray dried powder obtained $(g)$

$\overline{\text { Weight of feed mixture subjected for spray drying }(g)} \times 100$

\section{Statistical analysis}

Data obtained in the assays were subjected to statistical analysis using "Web Agri Stat
Package 2" of ICAR Research Complex, Goa. ' $F$ ' test at $p=0.01$ was performed to assess the level of significance. Critical difference values were calculated where the ' $F$ ' test was significant.

\section{Results and Discussion}

\section{Moisture}

Moisture content is an important attribute of the dehydrated products and essential property of powders to decisive the powder stability and storage (Phisut, 2012). In spray drying, the moisture content can be bought to a desired critical level so that the storability and nutritional stability can be maintained for a long period. The process of dehydration was quite easier as the biochemical makeup of avocado pulp characterized by lower sugar content.

The moisture content of avocado pulp was $73.56 \%$ (Table 1) whereas in spray dried powderit was ranged from 1.85 to 3.76 percent as shown in Table 2. It was found that higher inlet drying temperatures favored minimal moisture levels (Tonon et al., 2011). At higher inlet temperature the rate of heat transfer is greater, which favors high driving force for moisture evaporation and so decreased the moisture (Caliskan, 2013; Fazaeli, 2012; Quek et al., 2007; Chegini and Ghobadian, 2005). There was a striking linear correlation between the intel temperature and residual moisture content and the same was reported by Patil et al., (2014) in spray-dried guava powder and Tze et al., (2012) in pitaya fruit powder. Spray-dried powders with lower residual moisture content are characterized by a higher degree of rehydration capacity (Goula and Adamopoulos, 2008) which the most desirable attributes in terms of quality. Meanwhile, powders obtained at higher temperatures were more hygroscopic and exhibited particles with a finer and smooth surface (Tonon et al., 2010) 


\section{Water activity}

Water activity indicates the available free water for various reactions occurring in the powder. Water activity values of avocado pulp was 0.691 (Table 1). Water activity values of spray-dried avocado powder significantly $(\mathrm{p} \leq 0.05)$ varied when subjected to varied inlet temperature which ranged from 0.174 to 0.251 . As the inlet temperature increased from the water activity decreased from 0.251 to 0.174 as shown in Table 2. and a similar trend was reported by Sarabandi et al., (2014).

Powders spray-dried at lower inlet temperature $\left(150{ }^{\circ} \mathrm{C}\right)$ had higher water activity indicating more free water availability for the biological activity and further reduced shelf life (Oberoi and Sogi, 2015). Generally, water activity is directly correlated with moisture content irrespective of the nature of the product. High values for water activity indicate more free water available for biochemical reactions and microbial, shorter shelf life (Quek et al., 2007).

\section{Colour}

The colour values of spray dried avocado powder varied significantly when compare to pulp values as shown in Table 1.

\section{$L$ values}

L values of spray-dried avocado powder varied significantly among the different drying temperatures. As the inlet temperature increased from $150{ }^{\circ} \mathrm{C}$ to $180{ }^{\circ} \mathrm{C}$ there was a significant $(\mathrm{p} \leq 0.05)$ swift in $\mathrm{L}$ values from 66.36 to 72.17 as shown in Table 2. The degree of lightness ( $\mathrm{L}$ values) was found to be maximum at higher inlet drying temperature indicating the depletion of color from dark green to light green in spray-dried avocado samples.

\section{a values}

The values of a indicate the degree of greenness (-a) and redness $(+a)$ of the product. The values of spray-dried powder ranged from +0.26 to +3.44 as shown in Table 2. The higher inlet temperature had an obstructive effect on the degree of greenness of the power when compared to that of fresh pulp (a value). The green color retention was closer to the fresh pulp when the samples were dried at the inlet temperature of $150{ }^{\circ} \mathrm{C}$ with a value of +0.26 . The bleaching effect of green color on the spray-dried avocado powder was due to the thermal degradation of the chlorophyll and other associated pigments which are thermolabile.

\section{b values}

The $b$ values indicate the degree of blueness $(-b)$ and yellowness $(+b)$ of the product. There was a significant difference among the yellowness of powders spray-dried at a different inlet temperature of $150{ }^{\circ} \mathrm{C}, 160^{\circ} \mathrm{C}$, $170{ }^{\circ} \mathrm{C}$, and $180{ }^{\circ} \mathrm{C}$ ranging from 19.73 to 31.84 as shown in Table 2 . As the inlet drying temperature increased, Parallel to it yellowness also increased indicating the bleaching of green color from the powder and attaining the different degree of yellowness.

\section{Chroma}

Chroma values of spray-dried avocado powder increased gradually from 19.73 to 32.03 as the inlet temperature varied from 150 ${ }^{\circ} \mathrm{C}$ to $180^{\circ} \mathrm{C}$ as shown in Table 2 indicating a shift in the color from light green to greenishyellow which is due to loss of green color at higher inlet temperatures.

\section{Hue}

Hue values decreased from 89.24 to 83.82 as the inlet temperature increased from $150{ }^{\circ} \mathrm{C}$ to 
$180^{\circ} \mathrm{C}$ as shown in Table 2, which indicates a slight browning in samples and shift towards redness from yellow colour.

\section{Wettability (s)}

Wettability is the potentiality of the powder bulk to completely rehydrate and sink into water (Gaiani et al., 2007). The amount of time taken by the powder to settle down at the bottom of the container is measured in terms of wettability and can also be referred to as sink ability. Wettability values for spray-dried avocado powder varied from 71.40 to $104.00 \mathrm{~s}$ as shown in Table 2. At higher inlet temperature wettability of the powder decreased proportionally due to low levels of residual moisture in the powders (Borges et al., 2002). In addition to it, Bhandari et al., (1993) reported that the wettability of fruit powder in lower inlet air temperature is better than the higher inlet air temperature. This difference in opinion may be due to the moisture content and particle size of the powder. Moreover, wettability is influenced by boundless factors such as particle size, porosity, density, surface charge, surface area, absence/presence of amphipathic substances (Vega and Roos, 2006). Thus in the avocado powder, higher inlet temperature favored desired wettability.

\section{Bulk density and tap density}

Bulk density and tap density of the powder varied significantly among the different drying inlet temperatures which ranged from 0.41 to 0.49 as shown in Table 2. Drying at higher inlet temperatures will aid in attaining minimal residual moisture level which will significantly affect the bulk density and so the tap density, the powder obtained at $180{ }^{\circ} \mathrm{C}$ inlet drying temperature had the lowest bulk density and tap density and were more desirable as the intention of drying is to reduce the bulk density of the products. The moisture content of the samples significantly influenced the bulk density and tap density as the presence of higher moisture content, will increase the bulky nature of the powder which will be denser than the solid particles (Chegini G. R. and Ghobadian B., 2007, Zare et al., 2012). Similarly, spray-dried Jamun fruit powders were significantly influenced by the inlet temperature, with lower tap density for higher inlet temperature (Santhalakshmy et al., 2015). In general, higher inlet air temperatures result in powders with lower density, which is due to the higher drying temperature that causes faster particle drying with less shrinkage in droplets giving lower powder density (Fazaeli et al., 2012).

Table.1 Moisture, Water activity and Colour (L a b) of avocado fruit pulp

\begin{tabular}{|c|c|c|}
\hline \multicolumn{2}{|c|}{ Parameters } & Values \\
\hline \multicolumn{2}{|c|}{ Moisture } & 73.56 \\
\hline Water Activity & & 0.691 \\
\hline Colour & L & 49.31 \\
\hline & a & -3.4 \\
\hline & b & 34.93 \\
\hline
\end{tabular}


Table.2 Influence of intel temperature on the physical properties of spray dried avocado powder

\begin{tabular}{|c|c|c|c|c|c|c|c|c|c|c|c|c|c|}
\hline \multirow{2}{*}{$\begin{array}{c}\text { Treatments } \\
\text { (Inlet } \\
\text { Temperature) }\end{array}$} & \multirow{2}{*}{$\begin{array}{c}\text { Moisture } \\
\text { Content } \\
(\%)\end{array}$} & \multirow{2}{*}{$\begin{array}{c}\text { Water } \\
\text { activity }\end{array}$} & \multicolumn{5}{|c|}{ Colour values } & \multirow{2}{*}{$\begin{array}{c}\text { Wettability } \\
\text { (s) }\end{array}$} & \multirow{2}{*}{$\begin{array}{c}\text { Bulk } \\
\text { density } \\
\left(\mathrm{g} / \mathrm{cm}^{3}\right)\end{array}$} & \multirow{2}{*}{$\begin{array}{c}\text { Tap } \\
\text { density } \\
\left(\mathrm{g} / \mathrm{cm}^{3}\right)\end{array}$} & \multirow{2}{*}{$\begin{array}{c}\text { Hausner } \\
\text { Ratio }\end{array}$} & \multirow{2}{*}{$\begin{array}{l}\text { Carr's } \\
\text { Index }\end{array}$} & \multirow{2}{*}{$\begin{array}{c}\text { Powder } \\
\text { yield } \\
(\%)\end{array}$} \\
\hline & & & $\mathbf{L}$ & $\mathbf{a}$ & b & C & $\mathbf{H}$ & & & & & & \\
\hline $150^{\circ} \mathrm{C}$ & $3.76^{\mathrm{a}}$ & $0.251^{\mathrm{a}}$ & $66.36^{c}$ & $0.26^{\mathrm{d}}$ & $19.73^{c}$ & $19.73^{c}$ & $89.24^{\mathrm{a}}$ & $104.00^{\mathrm{a}}$ & $0.49^{\mathrm{a}}$ & $0.69^{\mathrm{a}}$ & $1.41^{\mathrm{d}}$ & $29.18^{c}$ & $6.04^{c}$ \\
\hline $160^{\circ} \mathrm{C}$ & $2.49^{b}$ & $0.204^{b}$ & $68.27^{b}$ & $0.65^{c}$ & $27.44^{\mathrm{b}}$ & $27.45^{b}$ & $88.64^{b}$ & $89.60^{b}$ & $0.45^{b}$ & $0.65^{\mathrm{b}}$ & $1.45^{\mathrm{c}}$ & $31.07^{b}$ & $9.79^{a}$ \\
\hline $170^{\circ} \mathrm{C}$ & $2.35^{\mathrm{c}}$ & $0.184^{b c}$ & $68.93^{b}$ & $2.36^{\mathrm{b}}$ & $28.53^{b}$ & $28.63^{b}$ & $85.27^{\mathrm{c}}$ & $78.60^{c}$ & $0.41^{c}$ & $0.60^{c}$ & $1.49^{b}$ & $32.80^{\mathrm{a}}$ & $6.10^{c}$ \\
\hline $180^{\circ} \mathrm{C}$ & $1.85^{\mathrm{d}}$ & $0.174^{\mathrm{c}}$ & $72.17^{a}$ & $3.44^{\mathrm{a}}$ & $31.84^{\mathrm{a}}$ & $32.03^{\mathrm{a}}$ & $83.82^{d}$ & $71.40^{d}$ & $0.41^{c}$ & $0.60^{\mathrm{d}}$ & $1.50^{\mathrm{a}}$ & $33.45^{\mathrm{a}}$ & $7.33^{b}$ \\
\hline Mean & 2.61 & 0.203 & 68.93 & 1.68 & 26.88 & 26.94 & 86.74 & 85.90 & 0.44 & 0.63 & 4.72 & 31.62 & 7.30 \\
\hline S. Em \pm & 0.05 & 0.01 & 0.27 & 0.06 & 0.44 & 0.44 & 0.12 & 0.82 & 0.01 & 0.01 & 0.01 & 0.23 & 0.32 \\
\hline C. D. at $5 \%$ & 0.17 & 0.020 & 0.80 & 0.17 & 1.30 & 1.30 & 0.37 & 2.45 & 0.02 & 0.02 & 0.01 & 0.69 & 0.94 \\
\hline
\end{tabular}




\section{Hausner ratio and Carr's index}

Hausner ratio and Carr's index will represent the cohesiveness and flowability attributes of the powder respectively. On the report of standard value to detect good flowability, the compressibility index must be within 15\% and the Hausner ratio within 1. It is observed from Table 2 that both the Carr's index and the Hausner ratio values increased with the increase in inlet temperature. The Hausner ratio and Carr's index for the spray-dried avocado powder ranged from 1.41- 1.50 and 29.18 - 33.45 respectively. Which indicated the poor flowability attributes which are due to high-fat content in powder.

\section{Powder yield}

Drying at $160{ }^{\circ} \mathrm{C}$ increased the powder yield compared to other drying temperatures i.e., $150^{\circ} \mathrm{C}, 170{ }^{\circ} \mathrm{C}$, and $180^{\circ} \mathrm{C}$ as shown in Table 2. An increase in the intel temperature from 150 to $160^{\circ} \mathrm{C}$ led to an increase in the powder yield which is due to greater efficiency of heat and mass transfer (Chegini and Ghobadian, 2007; Cai and Corke, 2000). Similar results for the influence of inlet temperature on recovery of the black mulberry juice powder were reported by Fazaeliet al., 2012. After a certain level i.e., above $160{ }^{\circ} \mathrm{C}$ the power yield decreased significantly by increasing the inlet temperature and causing stickiness and melting of powder on the dryer walls (Chegini and Ghobadian (2007) and Dolinsky (2001). This is a primary factor affecting the process yield which is caused due to glass transition temperatures and the same was reported by Normand, et al., 2013; Woo et al., 2008.

In conclusion, spray drying at different inlet temperature had a significant effect on the physical attributes of spray-dried avocado powder. Though the desirable physical attributes such as moisture content $(1.85 \%)$,
Water activity (0.17), and bulk density (0.41) were obtained at higher inlet temperatures of $180{ }^{\circ} \mathrm{C}$, the attractive greenish color tinge in powders was reported at $150{ }^{\circ} \mathrm{C}$. With respect to yield, drying at $160{ }^{\circ} \mathrm{C}$ inlet temperature was found to be more ideal.

\section{References}

Bhandari, B.R., Senoussi, A., Dumoulin, E. D., and Lebert, A. 1993. Spray drying of concentrated fruit juices. Drying Technology. 11(5): 1081-1092.

Borges, S. V., Reis, A. L. S. H., Jorge, E. C., Pinto, P. R. and Oliveira, V. M. 2002. Jugo de frutastropicalesdeshidratadospor spray drying. Alimentaria. 334: 125-130.

Buffo, R. A., Probst, K., Zehentbauer, G., Luo, Z. and Reineccius, G. A. 2002. Effects of agglomeration on the properties of spraydried encapsulated flavours. Flavour and Fragrance Journal. 17: 292-299.

Cai, Y. Z. And Corke, H. 2000. Production and properties of spray-dried Amaranthus betacyanin pigments. Journal of Food Science. 65: 1248-1252

Caliskan, G. and Dirim, S. N. 2013. The effects of the different drying conditions and the amounts of maltodextrin added during the spray drying of sumac extract. food and bioproducts processing. 91: 539-548.

Carr R. L. 1965. Evaluating flow properties of solids. Chemical Engineering Journal. 72 (3): 163-168.

Champagne, C. M., Broyles, S. T., Moran, L. D., Cash, K. C., Levy, E. J. and Lin, P. H. 2011. Dietary Intakes Associated with Successful Weight Loss and Maintenance during the Weight Loss Maintenance Trial. Journal of the American Dietetic Association. 111: 1826-1835.

Chegini, G. R. and Ghobadian, B. 2007. Effect of spray-drying conditions on physical properties of orange juice powder. Drying Technology. 23(3): 657-668.

Chegini, G. R. and Ghobadian, B. 2005. Effect of spray drying conditions on physical properties of orange juice powder, Drying Technology. 23: 657-668.

Chegini, R. G. and Ghobadian, B. 2007, Spray 
dryer parameters for fruit juice drying. W. J. Agricultural science. 3: 230-236.

Comerford, K. B., Ayoob, K. T., Murray, R. D. and Atkinson, S.A. 2016. The role of avocados in complementary and transitional feeding. Nutrients. 8: 316.

Dolinsky, A. 2001. High temperature spray drying methods. Drying Technology. 19: 785-806.

Fang. Y., Selomulya, C. and Chen X. 2008. On measurement of food powder reconstitution properties. Drying Technology. 26: 3-14.

Fazaeli, M. Emam-Djomeh, Z. Ashtari, A.K. and Omid, M. 2012. Effect of spray drying conditions and feed composition on the physical properties of black mulberry juice powder. food and bioproducts processing. 90: 667-675.

Gaiani, C., Scher, J., Ehrhardt, J. J., Linder, M., Schuck, P., Desobry, S., and Banon, S. 2007. Relationships between dairy powder surface composition and wetting properties during storage: Importance of residual lipids. Journal of agricultural and food chemistry. 55:6561-6567.

Goula, A. M. and Adamopoulos, K. G. (2008). Effect of maltodextrin addition during spray drying of tomato pulp in dehumidified air: II. Powder properties. Drying Technology. 26: 726-737.

Hausner, H. H. 1967. Friction conditions in a mass of metal powder. International Journal of Powder Metallurgy. 3: 7-13.

Jumah, R.Y. Tashtoush, B. Shaker, R. R. and Zraiy, A.F. 2000. Manufacturing parameters and quality characteristics of spray dried jameed. Drying Technology.18 (4-5): 967-984.

Marulanda, A., Ruiz-Ruiz, M. and CortesRodriguez, M. 2018. Influence of spray drying process on the quality of avocado powder: a functional food with great industrial potential. Vitae. 25(1): 37-48.

Minh N. P., Them, L. T., Trinh, N. T. L., Linh, N. T. M., Cam Tu, C. N. and Tri, L. T. 2019. Several Parameters Influencing to the Production of Avocado (Persea americana) Powder. Journal of Pharmaceutical Sciences and Research.11(2): 289-294.

Normand, V., Subramaniam, A., Donnelly, J. and Bouquerand, P. E. 2013. Spray drying: Thermodynamics and operating conditions.
Carbohydrate Polymers, 97(2): 489-495.

Oberoi, D. P. S. and Sogi, D. S. 2015. Effect of drying methods and maltodextrin concentration on pigment content of watermelon juice powder. Journal of Food Engineering. 165: 172-178.

Patil, V., Chauhan, A. K. and Singh, S. P. 2014. Influence of spray drying technology on the physical and nutritional properties of guava powder. International Journal of Current Microbiology and Applied Sciences. 3(9): 1224-1237.

Phisut, N. 2012. Spray drying technique of fruit juice powder: some factors influencing the properties of product. International Food Research Journal. 19(4): 1297-1306.

Quek, S. Y., Chok, N. K. and Swedlund, P. 2007. The physiochemical properties of spraydried watermelon powders. Chemical Engineering and Processing. 46: 386-392.

Rawson, A., Patras, A., Tiwari, B.K., Noci, F., Koutchma, T. and Brunton, N. 2011. Effect of thermal and non thermal processing technologies on the bioactive content of exotic fruits and their products: Review of recent advances. Food Research International. 44(7): 1875-1887.

Rodriguez-Sanchez, D. G., Flores-Garcia, M., Silva-Platas, C., Rizzo, S., Torre-Amione, G., De la Pena-Diaz, A. and Garcia-Rivas, G. 2015. Isolation and chemical identification of lipid derivatives from avocado (Persea americana) pulp with antiplatelet and antithrombotic activities. Food and Function. 6(1): 92-202.

Rodriguez-Sanchez, D., Silva-Platas, C., Rojo, R. P., Garcia, N., Cisneros-Zevallos, L., Garcia-Rivas, G. and Hernandez-Brenes, C. 2013. Activity-guided identification of acetogenins as novel lipophilic antioxidants present in avocado pulp (Persea americana). Journal of Chromatography. 942: $7-45$.

Santhalakshmy, S., Bosco, S. J. D., Francis, S. and Sabeena, M. 2015. Effect of inlet temperature on physicochemical properties of spray-dried jamun fruit juice powder. Powder Technology. 274: 37-43.

Sarabandi, K., Peighambardoust, S. H. and Shirmohammadi, M. 2014. Physical properties of spray dried grape syrup as 
affected by drying temperature and drying aids. International Journal of Agriculture and Crop Sciences. 7(12): 928-934.

Sloth, B., Due, A., Larsen, T.M., Holst, J. J., Heding, A. and Astrup, A. 2009. The Effect of a High-MUFA, Low- Glycaemic Index Diet and a Low-Fat Diet on Appetite and Glucose Metabolism during a 6-Month Weight Maintenance Period. British Journal of Nutrition. 101: 1846-1858.

Tonon, R. V., Freitas, S. S. and Hubinger, M. D. 2010. Spray drying of acai (Euterpe oleraceae Mart.) juice: Effect of inlet air temperature and type of carrier agent. Journal of Food Processing and Preservation. 35: 691-700.

Tonon, V. R., Brabet, C. and Hubinger, M. 2011. Spray drying of acai juice: Effect of inlet temperature and type of carrier agent. Journal of Food Processing and Preservation. 5: 691-700.

Tze, N. L., Han, C. P., Yusof, Y. A., Ling, C. N., Talib, R. A., Taip, F. S. and Aziz, M. G. 2012. Physicochemical and nutritional properties of spray-dried pitaya fruit powder as natural colorant. Food Science and Biotechnology. 21(3): 675-682.

Vega, C. and Roos, Y. H. 2006. Spray-dried dairy and dairy-like emulsions compositional considerations. Journal of Dairy Science.
89: 383-401.

Victor, L. Fulgoni, Mark, D. and Davenport, A. J. 2013. Avocado consumption is associated with better diet quality and nutrient intake, and lower metabolic syndrome risk in US adults: results from the National Health and Nutrition Examination Survey (NHANES) 2001-2008. Nutrition Journal. 12(1): 1-6.

Vissotto, F. Z., Jorge, L. C., Makita, G. T., Rodrigues, M. I. and Menegalli, F. C. 2010. Influence of the process parameters and sugar granulometry on cocoa beverage powder steam agglomeration. Journal of Food Engineering. 97(3): 283-291.

Walton, D. E. 2000. Morphology of spray-dried particles. Drying Technology, 18 (3): 19441986.

Woo, M. W., Daud, W. R. W., Mujumdar, A. S., Wu, Z., MeorTalib, M. Z. and Tasirin, S.M. 2008. CFD evaluation of droplet drying models in a spray dryer fitted with a rotary atomizer. Drying Technology: 26(10): 1180-1198.

Zare, D., Salehi A. and Niakousari, M. 2012. determination of physical properties of sour orange juice powder produced by a spray dryer. Written for presentation at the 2012 ASABE Annual International Meeting Sponsored by ASABE Hilton Anatole Dallas, Texas July 29 - August 1, 2012.

\section{How to cite this article:}

Karthik Nayaka, V. S., Shamina Azeez, G. J. Suresha, R. B. Tiwari, S. J. Prasanth, G. Karunakaran and Suresha, K. B. 2020. Influence of Inlet Drying Temperature on the Physical Attributes of Spray Dried Avocado (Persea americana Mill) Powder. Int.J.Curr.Microbiol.App.Sci. 9(12): 1761-1770. doi: https://doi.org/10.20546/ijcmas.2020.912.208 